Senanayake, G.P.D.P. and Chandanie, H., 2021. Assuring sustainable construction at project feasibility stage in Sri Lanka. In: Sandanayake, Y.G., Gunatilake, S. and Waidyasekara, K.G.A.S. (eds). Proceedings of the $9^{\text {th }}$ World Construction Symposium, 9-10 July 2021, Sri Lanka. [Online]. pp. 134-146. DOI: https://doi.org/10.31705/WCS.2021.12. Available from: https://ciobwcs.com/papers/

\title{
ASSURING SUSTAINABLE CONSTRUCTION AT PROJECT FEASIBILITY STAGE IN SRI LANKA
}

\author{
G.P.D.P. Senanayake ${ }^{1}$ and H. Chandanie ${ }^{2}$
}

\begin{abstract}
Construction activity is commonly considered to have adverse impacts on the environment, which is the basis of sustainable development for human being. Further, sustainability should be addressed mostly in developing countries, such as Sri Lanka, where a considerable amount of construction works is currently in progress and remain to emerge in the future. It is considered that the proper development and operation of a construction project can make significant contribution to the mission of sustainable development. However, the existing difficulty is the lack of the guidance for implementing sustainable development principles in construction industry. Therefore, this research intends to bring the necessity of mandated project feasibility studies as a guideline for sustainable development in the Sri Lankan Context. The research aim was approached through a qualitative survey strategy. To solicit the perceptions of experts on the identified sustainability performance criteria, a semi-structured interview survey was conducted. Ten experts were selected through purposive sampling strategy, who had experience in sustainable construction and project feasibility evaluation criteria. The manual content analysis method was used to analyse the collected data. Findings of the research revealed that though numerous sustainability assessment tools are being practised, there is a failure in sustainable construction in the current context. Thus, the minimum sustainability requirements were identified under the three pillars of sustainability, aiming to develop the project feasibility study as a guideline and to ensure sustainability performance from the project inception stage. These findings are helpful for industry practitioners especially the project owners to initiate a sustainable construction with concerted actions of all project stakeholders to safeguarding the future.
\end{abstract}

Keywords: Government policies, Minimum sustainability requirements, Project feasibility study, Sri Lanka, Sustainable construction.

\section{INTRODUCTION}

The construction industry and its activities have significant impact on the environment economy, and society (Osei, 2013). Further, the construction industry is continuously exploring appropriate strategies required to make constructions more sustainable (Abidin, 2010; Kandil et al., 2010), due to its negative impact (Sfakianaki, 2019). Appreciation of the significant impacts of construction activities on Sustainable Development (SD) has led to the development of various management approaches and methods to guide construction participants in achieving better project sustainability performance. However,

\footnotetext{
${ }^{1}$ Department of Building Economics, University of Moratuwa, Sri Lanka, gayasena98@gmail.com

${ }^{2}$ Department of Building Economics, University of Moratuwa, Sri Lanka, chandanieh@uom.lk
} 
government policies and regulations act as the primary solution to mitigate adverse effects from construction activities (Zhang et al., 2012).

The SD was defined in Brundtland's report published by World Commission on Environment and Development as meeting the current generation's necessities and aspirations without minimising the future potential (World Commission on Environment and Development (WCED), 1987, p. 43). When concerning construction as a business, the fusion of sustainability is about achieving a mutually beneficial outcome for project stakeholders and a satisfactory profit for the developers (Hutchins and Sutherland, 2008; Zuo and Zhao, 2014). Sustainability performance of an individual construction project across its life cycle is an indispensable aspect in attaining the goal of SD. Hence, incorporating them in the project's inception stage is the most critical phase for sustainable decision-making (Braganca et al., 2010; Heralova, 2017). Although Environmental Impact Assessment (EIA) and feasibility study include sustainable assessment criteria at early construction stages (Li et al., 2010), only EIA is under the legal system of environmental protection as the guideline for the ecological consequences. Therefore, implementing a feasibility study as a policy guideline to comply with sustainable requirements may be the best option as feasibility criteria are better matched with the three pillars of sustainability.

Generally, the implementation of Sustainable Construction (SC) practices in developing countries was found to be low (Abidin, 2010; AlSanad, 2015). Sri Lanka (SL), as a developing country, has a high demand for SC even though the country is not adequately furnished with SC practices (Jayalath and Gunawardhana, 2017). The research findings of Athapaththu and Karunasena (2018) suggested that contracting organisations established in SL lack in adopting existing SC practices. The proper implementation of SC has been obstructed by many barriers (Adetunji et al., 2003), where lack of project owner's demand has been considered as the main barrier for SD (Pitt et al., 2009). However, SD is still regarded as a 'nice-to-have' practice by the owners that enhances usual practice without being incorporated into decision making (Du Plessis, 2002). Therefore, governments can explicitly assist in introducing sustainability into the construction sector through policies and guidelines while balancing the interests among economic, social, and environmental stakeholders through rewards and penalties (Chong et al., 2009). Shen et al. (2010) identified the existing social, economic, and environmental attributes relating to sustainability in the project feasibility study. Yet, there is a research gap in studying the shifting of the traditional method of a project feasibility study to a new path while embracing the principles of SD in the Sri Lankan Context. Thereby, it is necessary to research minimum sustainability requirements in implementing the project feasibility study as a policy guideline for every project within a country. This research aims to discover minimum sustainability requirements to embrace the principles of SD into project feasibility checks on construction work in SL. The aim was achieved by critically reviewing the relationship between feasibility studies and assuring sustainability to identify sustainability performance criteria at project inception stage and accomplishing the minimum sustainability requirements essential to be achieved by construction projects from the country perspective. 


\section{LITERATURE REVIEW}

\subsection{The Relationship BetWeEn Project FeasibiLity STUdies AND ASSURING SUSTAINABILITY}

The concepts of SD should be integrated into all stages of the project life cycle (Tam et al., 2012). The Royal Institute of British Architects (RIBA) Plan of Work organises the project life cycle into a process of eight (08) stages: i.e. (i) strategic definition, (ii) preparation and briefing, (iii) concept design, (iv) spatial coordination (v) technical design, (vi) manufacturing and construction, (vii) handover, and (viii) use of a building (Royal Institute of British Architects (RIBA), 2020). The different sustainability tools have been developed to evaluate the success of the development over the stages of the project life cycle in terms of balancing energy and environment while considering the social and technological aspects (Clements-Croome, 2004). Even though there are number of sustainability assessment tools, the time of application (Wilkinson and Reed, 2007), single-dimensional nature (Ding, 2008), regional variations (Kohler, 1999), complexity (Crawley and Aho, 1999), lack of government intervention are identified as limitations of current sustainability assessment tools to achieve SC.

The early involvement of stakeholders, even before the design stage, will ensure the successful execution of SC (Tam et al., 2012). Hill and Bowen (1997) suggested that more attention should be given to the application of environmental, social, and economical assessment for implementing a construction project in particular at project feasibility stage. At this stage, the new project will be investigated with multiple options while addressing the issues in such a way as to why, when, and how to invest (Shen et al., 2007). The preliminary feasibility study and the project proposal are conducted at this stage, where the most feasible option will be detailed into a proposal with the needed sustainable activities of the client to make the investment decision (Shen et al., 2007). However, the effectiveness of sustainability assessment tools at the inception stage is limited due to the limited project information at the beginning (Shen et al., 2010). Hence, the sustainability criteria that can be assessed in the project's inception have been identified by Shen et al. (2007). Shen et al. (2010) had analysed 87 feasibility study reports of various types of projects in China and identified eighteen economic, nine social, and eight environmental performance attributes. Table 1 illustrates the findings of both papers.

Table 1: Sustainability criteria at the inception stage

\begin{tabular}{|c|c|c|}
\hline \multicolumn{3}{|c|}{ Sustainability criteria at Inception Stage } \\
\hline Economic & Social & Environmental \\
\hline $\begin{array}{l}\text { Governmental strategic } \\
\text { development policy }\end{array}$ & $\begin{array}{l}\text { Influence on the local social } \\
\text { development }\end{array}$ & $\begin{array}{l}\text { Eco-environmental } \\
\text { sensitivity of the }\end{array}$ \\
\hline Tax policy & Provision capacity of & project location \\
\hline Demand and supply analysis & employment & Ecological \\
\hline Market forecast & Provision capacity of public & assessment \\
\hline Project function and size & services & Air impacts \\
\hline Market competition & Provision capacity of public & Water impacts \\
\hline Location advantage & infrastructure facilities & Noise impacts \\
\hline Technology advantage & $\begin{array}{l}\text { Provision of the infrastructures } \\
\text { for other economic activities }\end{array}$ & Waste impact \\
\hline
\end{tabular}




\begin{tabular}{lll}
\hline \multicolumn{3}{c}{ Sustainability criteria at Inception Stage } \\
\hline Budget estimate & Safety standards & $\begin{array}{l}\text { Environmentally } \\
\text { friendly design }\end{array}$ \\
$\begin{array}{l}\text { Financing channels } \\
\text { Investment plan }\end{array}$ & Improvement to the public & Energy \\
Life cycle cost & Culth & ponsumption \\
Life cycle profit & conservation & Land consumption \\
Finance risk assessment & Development of new & \\
Return on Investment (ROI) & settlement and local & \\
Net Present Value (NPV) & communities & \\
Pay-back period & Land use & \\
Internal Rate of Return (IRR) & Safety assessment & \\
Scale and business scope & & \\
The effect on the local economy & & \\
\hline
\end{tabular}

Although the currently used environmental building assessment tools have given less attention to financial aspects, the project feasibility studies include more concern over financial criteria as per the table above. Hence, the number of SCs has been reduced in practice due to the profit-driven culture in the industry (Shen et al., 2010). Therefore, even the projects are environmentally friendly, and they will make it less attractive to developers as they may be too costly to build. Thus, both environmental issues and financial considerations should be given equal concern in the feasibility evaluation framework (Larsson, 1999), including environmental goals, sustainability certification, and the budget for sustainability. Hence, Shen et al. (2010) highlighted the necessity of shifting the project feasibility study to a new dimension by embracing more social and environmental principles of SD into it.

\subsection{OVERVIEW OF SUSTAINABLE CONSTRUCTION IN SRI LANKa}

The successful implementation of SD principles is a must to overcome environmental issues in developing countries (Zeng et al., 2002; Shen et al., 2005). Yet SL has not taken sufficient measures to mitigate the current challenges that occur in the construction industry (Jayalath and Gunawardhana, 2017). In SL, the GREENSL® rating system is introduced in 2010 by the Green Building Council of SL as an assessment tool to guide SC. Along with that, Tsunami Sustainable Building Guidelines for South-East Asia was published. It was a SC management guideline with several environmental, safety, and financial benefits (United Nations Environment Programme, 2007). There are 64 LEED, and GREEN ${ }^{\text {sl }}$ certified green buildings in SL (Green Building Council Sri Lanka (GBCSL), 2020). For example, Heritance Kandalama is one of the LEED Bronze rated hotels in the world (Seneviratne, 2014) and MAS Intimates Thurulie-Clothing Factory is the first LEED Platinum rated newly built manufacturing factory in the world (MAS Holdings, 2020).

The Sri Lankan government has already implemented several rules and regulations to support local green growth (Thalpage and Karunasena, 2016). The primary legislation for environmental conservation in SL was the National Environmental Act. According to this Act, Part IV C requires Environmental Impact assessment (EIA) approval for 'Prescribed Projects,' which are listed under the Act and government gazette notifications (De Mel et al., 2009). Further, there are many Physical Planning Acts and Ordinances such as Urban Development Authority (UDA) Law No 41 of 1978, Town and Country Planning 
Ordinance No. 16 of 1946, Housing and Town Improvement Ordinance No.19 of 1915, Municipal Council Ordinance, Urban Council Ordinance and Pradeshiya Sabha Act of 1987 for protection of the Environment and promoting economic, social, and physical development at early stages. However, the legal framework in SL has accomplished environmental aspects compared to economic and social issues (Abeynayake, 2010). Therefore, SL has experienced unsustainable development during the past decades. Abidin et al. (2012) argued that with more government actions, the construction activities will move towards better environmental, social, and economic safeguards. Yet there is a lack of policies and regulations that directly concerns Sustainability practices in SL compared to environmental protection (Hewage and Mallika, 2011). Finally, issuing the devised project feasibility criteria as a sustainability guideline as approval for project commencement will uplift the green building practices in SL.

\section{METHODOLOGY}

The major objective of this study is to find out the minimum sustainability requirements that can be incorporated into the project feasibility study to assure SC and used by all project participants to understand and improve sustainability performance at inception stage. The data used for data collection were mainly from a comprehensive literature review. The qualitative research approach was selected as the best method to collect data due to the lack of knowledge and experience on both sustainability and project feasibility study with Sri Lankan construction professionals and it is difficult to go for a large number of respondents for the data collection. A preliminary list of sustainability performance criteria gathered was presented through semi-structured interviews to the invited professionals for their comments. There were ten (10) experts with more than 20 years of experience. They were selected through judgemental sampling technique, including two (2) quantity surveyors from road projects, two (2) quantity surveyors from building projects, two (2) civil engineers from building projects, and four (4) civil engineers from water projects. These interview discussions provide valuable comments on the selection of the minimum sustainability requirements. However qualitative data obtained from expert interviews were analysed through manual content analysis by tracking the findings within identified themes.

\section{RESULTS}

Findings of the Expert survey can be elaborated under the three pillars of sustainability as identified in the literature review and the interviewee's opinions were analysed through manual content analysis and the obtained summary is presented in Table 2. Criteria in the Table includes literature findings in Table 1 and criteria from LEED sustainability assessment tool. The common view of the respondents was marked as " $\checkmark$ " in Table 2.

Out of 79 sustainability performance criteria identified, 77 were from the literature findings and remaining one was from expert interviews. That proposed criterion was Cost-Benefit Analysis (CBA). Then experts identified 68 criteria as minimum sustainability requirements to assess all the project at the feasibility stage as illustrated below. However, to make the project feasibility study as a guideline under the law of SL, the collected data was analysed to come up with the criteria which are not assessed in EIA and government authorities. Hence, ultimately 36 criteria were found to be the final output that need to be mandated to come up with the sustainable feasibility guideline. 
Table 2: Common view of the respondents

\begin{tabular}{|c|c|c|c|c|}
\hline Literature Findings & \multicolumn{4}{|c|}{ Common View of Expert Survey Findings } \\
\hline Sustainability performance criteria & $\begin{array}{l}\text { Minimum } \\
\text { sustainability } \\
\text { requirements }\end{array}$ & $\begin{array}{l}\text { Feasibility } \\
\text { study }\end{array}$ & EIA & $\begin{array}{l}\text { Government } \\
\text { authorities }\end{array}$ \\
\hline \multicolumn{5}{|c|}{ Economic sustainability factors } \\
\hline Government strategic development policy & $\checkmark$ & $\checkmark$ & $\checkmark$ & - \\
\hline Tax policy & $\checkmark$ & $\checkmark$ & - & - \\
\hline Market forecast & $\checkmark$ & $\checkmark$ & - & - \\
\hline Demand and supply analysis & $\checkmark$ & $\checkmark$ & - & - \\
\hline $\begin{array}{l}\text { Market competition (Sell/rent price } \\
\text { competition) }\end{array}$ & $\checkmark$ & - & - & - \\
\hline Project Promotion & $\checkmark$ & $\checkmark$ & - & - \\
\hline Project scope, scale, and functions & $\checkmark$ & $\checkmark$ & $\checkmark$ & - \\
\hline Effects on the local economy & $\checkmark$ & $\checkmark$ & - & - \\
\hline Location advantage & $\checkmark$ & $\checkmark$ & - & - \\
\hline Technology advantage & $\checkmark$ & $\checkmark$ & $\checkmark$ & - \\
\hline Budget estimate & $\checkmark$ & $\checkmark$ & - & - \\
\hline Financing channels & $\checkmark$ & $\checkmark$ & - & - \\
\hline Investment plan & - & $\checkmark$ & - & - \\
\hline Total life cycle cost and profit & $\checkmark$ & $\checkmark$ & - & - \\
\hline Financial risk assessment & $\checkmark$ & $\checkmark$ & - & - \\
\hline Overhead cost & - & $\checkmark$ & - & - \\
\hline Uncontrolled inflation. & $\checkmark$ & $\checkmark$ & - & - \\
\hline Fluctuation in foreign currency. & $\checkmark$ & - & - & - \\
\hline Return on investment (ROI) & - & $\checkmark$ & - & - \\
\hline Net present value (NPV) & - & $\checkmark$ & - & - \\
\hline Pay-back period & - & $\checkmark$ & - & - \\
\hline Internal rate of return (IRR) & - & $\checkmark$ & - & - \\
\hline Project Affordability & $\checkmark$ & $\checkmark$ & - & - \\
\hline Regulation in export-import limitation & $\checkmark$ & - & - & - \\
\hline Change in loan interest rate. & - & $\checkmark$ & - & - \\
\hline $\begin{array}{l}\text { Influences of domestic product and } \\
\text { resources use policy }\end{array}$ & $\checkmark$ & - & - & - \\
\hline Policy in stopping subsidy & $\checkmark$ & $\checkmark$ & - & - \\
\hline $\begin{array}{l}\text { Increasement in regional minimum } \\
\text { payment for workers. }\end{array}$ & $\checkmark$ & - & - & - \\
\hline Cost-Benefit Analysis & $\checkmark$ & $\checkmark$ & - & - \\
\hline \multicolumn{5}{|c|}{$\underline{\text { Social sustainability factors }}$} \\
\hline $\begin{array}{l}\text { Influence on local social development } \\
\text { (welfare) }\end{array}$ & $\checkmark$ & $\checkmark$ & - & - \\
\hline
\end{tabular}




\section{Literature Findings}

Common View of Expert Survey Findings

Provision of the infrastructures for public/ economic activities

Influence on land prices in the surrounding location.

Influence by surrounding people to the new development (protest)

Land use and its relationship with immediate surroundings

Provision capacity of employment

Provision capacity of public services (access to public services)

Improve public health and safety standards/ assessment

Cultural and heritage conservation

Development of new settlement and local communities/ resettlement

Thermal comfort

Day lightning and natural ventilation Acoustic performance and noise control Indoor air and water quality performance Low emitting materials

Indoor occupant health and safety quality performance

An unhealthy political climate for investment.

NGO involvement in the investment plan Lack of law enforcement.

Environmental sustainability factors

Access to the location

Influences of traffic jams around the location.

Unsupported facilities and other infrastructures around the location

Protection of environmentally sensitive project location

Selection of project location with high development priorities

Access to public and ecological transportation

Reduce parking footprint

Protect or restore natural habitats and promote biodiversity 


\begin{tabular}{|c|c|c|c|c|}
\hline Literature Findings & \multicolumn{4}{|c|}{ Common View of Expert Survey Findings } \\
\hline $\begin{array}{l}\text { Green space for environmental and social } \\
\text { interaction }\end{array}$ & $\checkmark$ & - & $\checkmark$ & - \\
\hline $\begin{array}{l}\text { Site assessment for sustainable design } \\
\text { options }\end{array}$ & $\checkmark$ & $\checkmark$ & - & $\checkmark$ \\
\hline \multirow{2}{*}{$\begin{array}{l}\text { Building water conservation } \\
\text { Leak detections and innovative water- } \\
\text { efficient equipment }\end{array}$} & $\checkmark$ & $\checkmark$ & - & $\checkmark$ \\
\hline & $\checkmark$ & - & - & - \\
\hline Water-efficient landscaping & $\checkmark$ & - & - & - \\
\hline Water recycling and reuse & $\checkmark$ & - & $\checkmark$ & - \\
\hline Rainwater management & $\checkmark$ & - & - & $\checkmark$ \\
\hline $\begin{array}{l}\text { Construction and demolition waste } \\
\text { management }\end{array}$ & $\checkmark$ & $\checkmark$ & $\checkmark$ & - \\
\hline $\begin{array}{l}\text { Innovative technologies for waste } \\
\text { reduction }\end{array}$ & $\checkmark$ & - & $\checkmark$ & - \\
\hline Optimise energy performance & $\checkmark$ & $\checkmark$ & - & - \\
\hline $\begin{array}{l}\text { Participation in demand response energy } \\
\text { technologies and programs }\end{array}$ & - & $\checkmark$ & - & - \\
\hline Renewable energy production & $\checkmark$ & - & - & - \\
\hline Enhanced refrigerant management & $\checkmark$ & - & - & - \\
\hline Recycle and renewable material use & $\checkmark$ & - & - & - \\
\hline Local and regional materials & $\checkmark$ & $\checkmark$ & - & - \\
\hline Environmentally friendly design & - & $\checkmark$ & - & - \\
\hline Building orientation & $\checkmark$ & - & - & - \\
\hline Air impacts & $\checkmark$ & - & $\checkmark$ & - \\
\hline Noise impacts & $\checkmark$ & - & $\checkmark$ & - \\
\hline Water impacts & $\checkmark$ & - & $\checkmark$ & - \\
\hline \multicolumn{5}{|c|}{ Other sustainability factors } \\
\hline Environmental Management Certificate & $\checkmark$ & - & $\checkmark$ & - \\
\hline $\begin{array}{l}\text { Green Building Accredited Experts to } \\
\text { support investment }\end{array}$ & $\checkmark$ & - & - & $\checkmark$ \\
\hline $\begin{array}{l}\text { Inappropriate technology in the } \\
\text { construction and operation phase }\end{array}$ & $\checkmark$ & - & - & - \\
\hline
\end{tabular}

\subsection{ECONOMIC SUSTAINABILITY CRITERIA}

Economic Performance Criteria (EPC) are used for assessing economic performance of construction projects. These criteria are used to reflect market availability, project financing and economic benefit from implementing a construction project. Through the literature findings, a list of EPC has been identified and they were directed to the interviewees to select minimum feasibility requirements.

It can be seen from Table 2 that out of the 29 EPC, 22 were selected as the minimum sustainability requirements at project feasibility study, 24 were already being assessed in the current project feasibility study, 3 were included in the EIA and no EPC were assessed 
in the governmental authorities. Hence it is clear that EPC were given less consideration in the mandated sustainable assessment criteria which were used for sustainable decision making at project inception stage.

As evident through the respondents' views, tax policy, project scope, scale and functions, location advantage, the influence of domestic product and resources use policy, technology advantage, and budget estimate are the most critical factors to be considered under economic sustainability requirements at project feasibility stage. Although these EPC are given good attention in conducting project feasibility study, market competition, fluctuation in foreign currency, regulation in export and import limitation, influence in domestic products and resource use policy, and increasement in regional minimum payment for workers were given limited attention in conducting project feasibility study where experts suggested them under the minimum sustainability requirements at feasibility stage.

Other than this, experts highlighted that tax policy needs to be implemented according to any framework where government should provide tax concessions and subsidy to identified projects to promote SC. Then that will expose to new technologies available in foreign countries it will increase the work efficiency. Further, the strategic development policy in SL changes with the government changes, where any strategy should be implemented through national policy as they are not changed with the ruling party.

\subsection{SOCIAL SUSTAINABILITY CRITERIA}

Social Performance Criteria (SPC) are used for assessing social performance of construction projects. Through the literature findings, a list of SPC have been identified and they were directed to the interviewees to select minimum feasibility requirements.

It can be seen from Table 2 that out of the 19 SPC, 17 were selected as the minimum sustainability requirements at project feasibility study, 13 were already being assessed in the current project feasibility study, 5 were included in the EIA and 3 of SPC were assessed in the governmental authorities. Same as EPC, SPC were also given less consideration in the mandated sustainable assessment criteria which were used for sustainable decision making at project inception stage.

It seems that social responsibilities have not been given due consideration in Sri Lankan projects. This is considered a major reason for causing the huge gap between the rich and the poor in the society. As evident through the respondents' views, influence on local social development, influence by surrounding people to new development, Land use and its relation with immediate surroundings, improve public health and safety standards/ assessment, cultural heritage conservation, development of new settlement/ local communities/ resettlements, unhealthy political climate, and lack of law enforcement are the most critical factors to be considered under social sustainability requirements at project feasibility stage. Although above SPC are given good attention in conducting project feasibility study, influence by surrounding people to new development, lack of law enforcement, and most of indoor environment quality criteria were given limited attention in conducting project feasibility study where experts suggested them under the minimum sustainability requirements at feasibility stage.

Moreover, to expert opinion, providing employment opportunities to local labourers will be a social benefit to the public as well as an economic benefit local economy, where indirectly the society will get indirect opportunities to earn by providing 
accommodations, shops. Further a proper law should be implemented through local government to approve building permit only if the sewerage line is taken up to the board connection.

\subsection{ENVIRONMENTAL SUSTAINABILITY CRITERIA}

Environmental Performance Criteria (EnPC) are used for assessing environmental performance of construction projects. In fact, a large number of research works have been conducted in this area and many EPC were identified compared to other pillars of sustainability. This may be because most works consider only the environmental factors when comes to the sustainability.

It can be seen from Table 2 that out of the 28 EnPC, 26 were selected as the minimum sustainability requirements at project feasibility study, 13 were already being assessed in the current project feasibility study, 12 were included in the EIA and 7 of EnPC were assessed in the governmental authorities. Hence it is clear that EnPC were given considerable attention in the mandated sustainable assessment criteria which were used for sustainable decision making at project inception stage. This is because EIA required on projects mainly concern on the four major environmental pollutions, including air, noise, water and waste.

As evident through the respondents' views, access to location, protect or restore natural habitats and promote biodiversity, green space for environmental and social interactions, site assessment for sustainable design options, air impacts, noise impacts, water impacts, and rainwater management are the most critical factors to be considered under environmental sustainability requirements at project feasibility stage. Although this EnPC are given good attention in conducting the project feasibility study, water conservation mechanisms, renewable energy production, enhanced refrigerant management, recycle and renewable material use, and building orientation were given limited attention in conducting project feasibility study where experts suggested them under the minimum sustainability requirements at feasibility stage.

As implementing construction projects has been a driving force to the economic growth in SL over previous decades, the effects of the construction industry on the degrading environment are huge. One of the major reasons for this is considered as the lack of consideration given to the environmental protection in the project feasibility study. Hence based on the above analysis, it is found that the EPC are given more concerns than that given to the SPC and EnPC in conducting construction project feasibility study.

\section{CONCLUSIONS}

SC is not yet standard practice in SL. This paper concludes that the proper development and operation of a construction project can make a significant contribution to the mission of SD. There is the existence of a lack of the guidance for implementing the SD principle in the construction business, and the lack of mechanism of assessing the practice of applying the principle at the project feasibility stage. Further, the traditional practice of assessing the feasibility of a construction project concerns more on the economic and social contribution of a construction project. Hence this research used project feasibility study as the sustainability tool to ensure SC from the inception stage earns the full benefits environmentally, socially, and economically by targeting the right group criteria. Hence, that right group includes 36 sustainability out of 79 to facilitate sustainability decision 
making. Based on those principles, the judgment can be made as to whether or not the development of a construction project is in line with SD principles. Thus, there was a requirement of guideline for sustainable decision making and it was fulfilled by assisting project feasibility study towards sustainability. It is proposed to implement the identified minimum sustainability requirements after benchmarking each criterion under possible government authority. However, this becomes an effective practice for SCs rather than governing under other sustainable assessment tools.

\section{REFERENCES}

Abeynayake, M.D.T.E., 2010. Legal aspects concerning sustainable buildings and cities relating to the urban development in Sri Lanka. International Research Conference on Sustainability in Built Environment, pp. 1-8. Available from: http://dl.lib.mrt.ac.lk/handle/123/14509.

Abidin, N.Z., 2010. Investigating the awareness and application of sustainable construction concept by Malaysian developers. Habitat International, 34(4), pp. 421-426.

Abidin, N.Z., Yusof, N. and Awang, H., 2012. A foresight into green housing industry in Malaysia. International Journal of Mechanical and Industrial Engineering, 6(7), pp. 373-381.

Adetunji, I., Price, A., Fleming, P. and Kemp, P., 2003. Sustainability and the UK construction industry a review. In Proceedings of the Institution of Civil Engineers-Engineering Sustainability, 156(4), pp. 185-199.

AlSanad, S., 2015. Awareness, drivers, actions, and barriers of sustainable construction in Kuwait. Procedia Engineering, pp. 118, pp. 969-983.

Athapaththu, K.I., and Karunasena, G., 2018. Framework for sustainable construction practices in Sri Lanka. Built Environment Project and Asset Management, 8(1), pp. 51-63.

Braganca, L., Mateus, R., and Koukkari, H., 2010. Building sustainability assessment. Sustainability, 2(7), pp. 2010-2023.

Chong, W.K., Kumar, S., Haas, C.T., Beheiry, S.M., Coplen, L. and Oey, M., 2009. Understanding and interpreting baseline perceptions of sustainability in construction among civil engineers in the United States. Journal of Management in Engineering, 25(3), pp. 143-154.

Clements-Croome, D. eds., 2004. Intelligent Buildings [Online]. London: Thomas Telford. Available from https://books.google.lk/books?hl=en\&lr=\&id=5EYU9jvsnvsC\&oi=fnd\&pg=PR7\&dq=ClementsCroome,+D.+eds.,+2004.+Intelligent+buildings+design,+management+and+operation.+London:+Tho mas+Telford.+\&ots=ZajFDLwWbw\&sig=VmYBm6oe-

LXvsRJ0Za8N_eahyBM\&redir_esc=y\#v=onepage\&q\&f=false [Accessed 14 January 2021]

Crawley, D. and Aho, I., 1999. Building environmental assessment methods: applications and development trends. Building Research and Information, 27(4- 5), pp. 300-308.

De Mel, M., Sirimanne, N., Nanayakkara, A., Rajapakshe, R., Gunawardhana, J., and Nanayakkara, R., 2009. Judges and Environmental Law [online]. Colombo: Environmental Foundation Limited. Available from https://www.ajne.org/sites/default/files/document/laws/5352/judges-environmentallaw-a-handbook-for-the-sri-lankan-judiciary.pdf [Accessed 20 January 2021]

Ding, G.K., 2008. Sustainable construction-The role of environmental assessment tools. Journal of Environmental Management, 86(3), pp. 451-464.

Du Plessis, C., 2002. Agenda 21 for sustainable construction in developing countries: a discussion document [online]. International Council for Research and Innovation in Building and Construction (CIB) and United Nations Environment Programme International Environmental Technology Centre (UNEP-IETC). Available from http://hdl.handle.net/10204/3511 [Accessed 20 December 2020]

Green Building Council Sri Lanka (GBCSL)., 2020. Green Building Council Sri Lanka. (AIVA) [online]. Available from http://srilankagbc.org/ [Accessed 1 February 2021]

Heralova, R.S., 2017. Life cycle costing as an important contribution to feasibility study in construction projects. Procedia Engineering, 196, pp. 565-570.

Hewage, T. and Mallika, K.V., 2011. Current trends in forest and environmental policies in Sri Lanka. International Forestry and Environment Symposium, pp. 1-12. Available from: https://core.ac.uk/download/pdf/228534714.pdf 
Hill, R.C. and Bowen, P.A., 1997. Sustainable construction: principles and a framework for attainment. Construction Management and Economics, 15(3), pp. 223-239.

Hutchins, M.J., and Sutherland, J.W., 2008. An exploration of measures of social sustainability and their application to supply chain decisions. Journal of Cleaner Production, 16(25), pp. 1688-1698.

Jayalath, A., and Gunawardhana, T., 2017. Towards sustainable constructions: Trends in Sri Lankan construction industry - A review. International Conference on Real Estate Management and Valuation 2017, pp. 137-143. Available from: http://icremv.sjp.ac.lk/assets/img/archive/2017.pdf\#page=158

Kandil, A., El-Rayes, K., and El-Anwar, O., 2010. Optimization research: enhancing the robustness of large-scale multiobjective optimization in construction. Journal of Construction Engineering and Management, 138(1), pp. 17-25.

Kohler, N., 1999. The relevance of green building challenge: An observer's perspective. Building Research and Information, 27(4-5), pp. 309-320.

Larsson, N.K., 1999. Development of a building performance rating and labelling system in Canada. Building Research and Information, 27(4-5), pp. 332-341.

Li, X., Zhu, Y., and Zhang, Z., 2010. An LCA-based environmental impact assessment model for construction processes. Building and Environment, 45(3), pp. 766-775.

MAS Holdings., 2020. Thurulie receives LEED platinum green building certification [Online]. Available from MAS Holdings: http://newsline.masholdings.com/ [Accessed 10 February 2021]

Osei, V., 2013. The construction industry and its linkages to the Ghanaian economy polices to improve the sector's performance. International Journal of Development and Economic Sustainability, 1(1), pp. 5672. Available from: https://pdfs.semanticscholar.org/80e8/e45bcb8be45a2dc11520c013a1f5d5326

Pitt, M., Tucker, M., Riley, M. and Longden, J., 2009. Towards sustainable construction: Promotion and best practices. Construction Innovation, 9(2), pp. 201-224.

Royal Institute of British Architects (RIBA)., 2020. RIBA plan of work 2020 [online]. RIBA, 66 Portland Place, London, W1B 1AD. Available from: https://www.architecture.com/-/media/GatherContent/Testresources-page/Additional-Documents/2020RIBAPlanofWorkoverviewpdf.pdf [Accessed 9 December 2020]

Seneviratne, M., 2014. Green buildings: A synergy with biodiversity [Online]. Available from http://www.ft.lk/other-sectors/green-buildings-a- synergy-with-biodiversity/57-322102 [Accessed 14 July 2014]

Sfakianaki, E., 2019. Critical success factors for sustainable construction: A literature review. Management of Environmental Quality, 30(1), pp. 176-196.

Shen, L. Y., Hao, J.L., Tam, V.W. and Yao, H., 2007. A checklist for assessing sustainability performance of construction projects. Journal of Civil Engineering and Management, 13(4), pp. 273-281.

Shen, L.Y., Tam, V.W., Tam, L., and Ji, Y.B., 2010. Project feasibility study: The key to successful implementation of sustainable and socially responsible construction management practice. Journal of Cleaner Production, 18(3), pp. 254- 259.

Shen, L.Y., Wu, Y.Z., Chan, E.H. and Hao, J.L., 2005. Application of system dynamics for assessment of sustainable performance of construction projects. Journal of Zhejiang University Science A, 6(4), pp. 339-349.

Tam, V.W., Shen, L.Y. and Sun, C.S., 2012. Reposition of the roles among project participants for improving construction project sustainability. International Journal of Construction Project Management, 5(1). pp 53-66.

Thalpage, R. and Karunasena, G. 2016. Approaches to foster green building constructions in Sri Lanka. $5^{\text {th }}$ World Construction Symposium 2016: Greening Environment, Eco Innovations and Entrepreneurship. pp. 70-78. Colombo: University of Moratuwa, Sri Lanka. Available from: https://www.researchgate.net/profile/Gayani_Karunasena/publication/324493150_Approaches_to_fos ter_green_building_constructions_in_Sri_Lanka/link s/5ad021a7aca2723a3346a0b3/Approaches-tofoster-green-building- constructions-in-Sri-Lanka.pdf.

United Nation Environment Programme., 2007. After Tsunami sustainable building guideline for SouthEast Asia [online]. Report No. 978-92-807-2782-1, Swiss Resource Centre and Consultancy for Development. Available from: https://wedocs.unep.org/20.500.11822/7911 [Accessed 12 January 2021] 
Wilkinson, S.J. and Reed, R.G., 2007. The structural and behavioural barriers to sustainable real estate development. 23 ${ }^{\text {rd }}$ American Real Estate Society (ARES) Conference, pp. 1-12. San Francisco, USA. Retrieved from http://dro.deakin.edu.au/view/DU:30022363

World Commission on Environment and Development (WCED), 1987. Report of the World Commission on Environment and Development: Our common future [Online]. Oxford; New York: Oxford University Press. Available from: http://www.environmentandsociety.org/mml/un-world-commissionenvironment-and-development-ed-report-world-commission-environment-and [Accessed 13 February 2021]

Zeng, S., Tam, C., Deng, Z. and Tam, W., 2002. ISO 14000 and the construction industry: Survey in China. Journal of Management in Engineering, 19(3), pp. 107-115.

Zhang, X., Wu, Y. and Shen, L., 2012. Application of low waste technologies for design and construction: A case study in Hong Kong. Renewable and Sustainable Energy, 16(5), pp. 2973-2979.

Zuo, J. and Zhao, Z., 2014. Green building research-current status and future agenda: A review. Renewable and Sustainable Energy Reviews, 30, pp. 271-281. 